\title{
Piperazinium Chlorocuprates(I)
}

Jacob E. Kuperstock

Amanda N. Ley

Robert D. Pike

William \& Mary, rdpike@wm.edu

Follow this and additional works at: https://scholarworks.wm.edu/aspubs

Part of the Chemistry Commons

\section{Recommended Citation}

Kuperstock, Jacob E.; Ley, Amanda N.; and Pike, Robert D., Piperazinium Chlorocuprates(I) (2009). Journal of Chemical Crystallography, 39(2), 131-137. https://doi.org/10.1007/s10870-008-9442-7

This Article is brought to you for free and open access by the Arts and Sciences at W\&M ScholarWorks. It has been accepted for inclusion in Arts \& Sciences Articles by an authorized administrator of W\&M ScholarWorks. For more information, please contact scholarworks@wm.edu. 


\section{Piperazinium Chlorocuprates(I).}

Jacob E. Kuperstock, Amanda N. Ley and Robert D. Pike*.

Department of Chemistry, College of William and Mary, Williamsburg, VA 23187.

Corresponding Author: $\quad$ Robert D. Pike

Department of Chemistry

College of William and Mary

Williamsburg, VA 23187-8795.

telephone: 757-221-2555

FAX: 757-221-2715

email: rdpike@wm.edu 
Index Abstract:

Piperazinium Chlorocuprates(I).

Jacob E. Kuperstock, Amanda N. Ley and Robert D. Pike*

The synthesis and network structures of four piperazinium hydrochlorides with copper(I) chloride are presented.

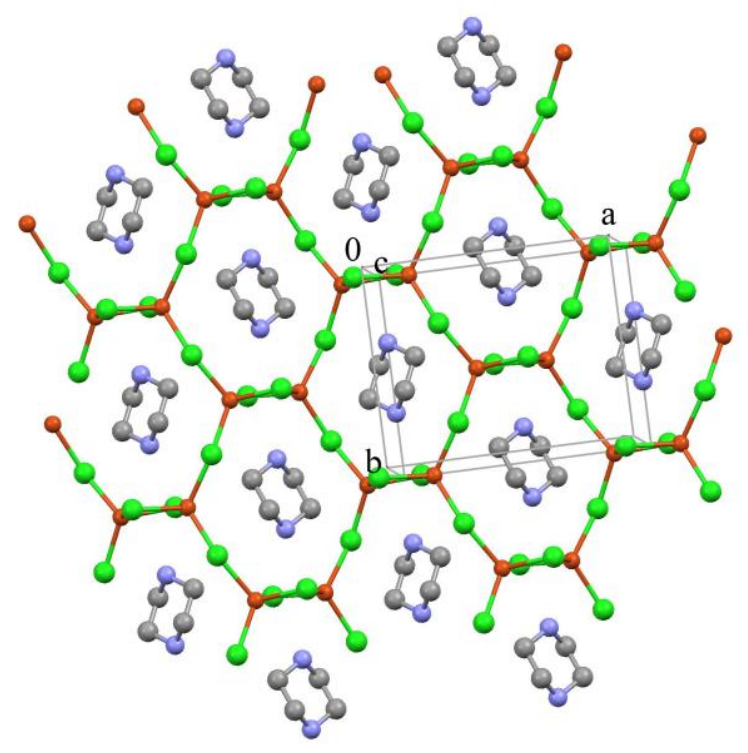




\title{
Piperazinium Chlorocuprates(I).
}

Jacob E. Kuperstock, Amanda N. Ley and Robert D. Pike*.

Department of Chemistry, College of William and Mary, Williamsburg, VA 23187.

\begin{abstract}
The formation from aqueous solution of networks containing piperazinium hydrochlorides with copper(I) chloride is described. Four new X-ray crystal structures are reported: ( $\left.\mathrm{H}_{2} \mathrm{Pip}\right)\left[\mathrm{Cu}_{2} \mathrm{Cl}_{4}\right]$ (two isomeric phases: $\mathbf{1 A}$ and $\mathbf{1 B}$ ), $\left(\mathrm{H}_{2} \mathrm{MePip}\right)\left[\mathrm{Cu}_{3} \mathrm{Cl}_{5}\right]$ (2), and $\left(\mathrm{H}_{2} \mathrm{Me}_{2} \mathrm{Pip}\right)\left[\mathrm{Cu}_{4} \mathrm{Cl}_{6}\right]$ (3) $\left(\mathrm{Pip}=\right.$ piperazine, MePip $=\mathrm{N}$-methylpiperazine, $\mathrm{Me}_{2} \mathrm{Pip}=\mathrm{N}, \mathrm{N}^{\prime}-$ dimethylpiperazine. In 1A $(P-1, a=6.3141(2), b=6.8248(2), c=6.9067(2), \alpha=90.707(2), \beta=$ 110.748(2), $\gamma=110.799(2), \mathrm{V}=256.918(13), \mathrm{Z}=2$ ) corner-sharing $\mathrm{Cu}_{2} \mathrm{Cl}_{2}$ rhomboid dimers form infinite chains running parallel to the $a$-axis. In 1B (Pbcn, $a=9.9442(6), b=8.0622(5), c=$ 13.1301(7), $\mathrm{V}=1052.67(11), \mathrm{Z}=8)$ the $\mathrm{Cu}_{2} \mathrm{Cl}_{2}$ dimers are linked by $\mu-\mathrm{Cl}$ into $\mathrm{Cu}_{6} \mathrm{Cl}_{8}$ rings which form hexagonally tiled sheets running parallel to the $a, b$ plane. In $2(P-1, a=8.0815(7), b$ $=9.6584(9), c=9.7900(8), \alpha=70.231(4), \beta=77.180(4), \gamma=70.587(4), V=673.05(10), Z=2)$ alternating $\mathrm{Cu}_{3} \mathrm{Cl}_{3}$ and $\mathrm{Cu}_{4} \mathrm{Cl}_{4}$ rings are fused to form ribbons that run parallel to the $a$-axis. Copper-copper interactions are present. In $3(C 2 / c, a=17.4026(6), b=10.5295(4), c=$ 11.7501(8), $\beta=131.5490(10), \mathrm{V}=1611.35(14), \mathrm{Z}=8$ ) relatively long $\mathrm{Cu} \cdots \mathrm{Cl}$ interactions connect $\mathrm{Cu}_{4} \mathrm{Cl}_{6}$ "adamantane" units into chains running parallel to the $c$-axis. In all cases the piperazinium ions are independent from the chlorocuprate structures, but they do show $\mathrm{N}-\mathrm{H} \cdots \mathrm{Cl}$ interactions.
\end{abstract}


Key Words: cuprate, piperazinium, polymer, polyanion, network

Shortened Title: Piperazinium Chlorocuprates(I).

\section{Introduction}

Transition metals readily form metallates through coordination of anionic ligands. Univalent Group 10 metals in particular are known to produce a wide range of oligomeric or polymeric polyhalides, $\left[\mathrm{M}_{\mathrm{n}} \mathrm{X}_{\mathrm{n}+\mathrm{y}}\right]^{\mathrm{y}-}(\mathrm{X}=\mathrm{Cl}, \mathrm{Br}, \mathrm{I})$ and polysulfides, $\left[\mathrm{M}_{2 \mathrm{n}} \mathrm{S}_{\mathrm{n}+\mathrm{y}}\right]^{2 \mathrm{y}-}$. Herein, we focus on halocuprate(I) anions, $\left[\mathrm{Cu}_{\mathrm{n}} \mathrm{X}_{\mathrm{n}+\mathrm{y}}\right]^{\mathrm{y}-}$, of which a large number are known, the majority forming simple corner-sharing chains, $\mathbf{I}^{1}{ }^{1}$ In other cases, further catenation is observed, producing polymeric species such as II - VII..$^{2-7}$ A few more unusual halocuprate arrangements have also been reported as well. ${ }^{8}$ Structures $\mathbf{I}-$ III are based solely on rhomboidal $\mathrm{Cu}_{2} \mathrm{X}_{2}$ units, which can share corners or edges, while the more complex structures VI - VII incorporate cyclic $\mathrm{Cu}_{3} \mathrm{X}_{3}$ and $\mathrm{Cu}_{4} \mathrm{X}_{4}$ units in addition to the ubiquitous $\mathrm{Cu}_{2} \mathrm{X}_{2}$. Terminal halides, such as seen in VI, are not common. The formation of $2 \mathrm{D}$ halocuprate networks is very rare with only three cases reported. Two of these are represented by structure VII, which consists of linked pairs of $(6,3)$ hexagonal $\mathrm{CuI}$ sheets. All copper and iodide ions are 4-coordinate, forming edge-sharing $\left(\mathrm{Cu}_{2} \mathrm{I}_{2}\right)_{3}$ propeller units having acute $\left(<70^{\circ}\right) \mathrm{Cu}-\mathrm{I}-\mathrm{Cu}$ angles. The remaining $2 \mathrm{D}$ halocuprate is a truncated version of VII in which $\left(\mathrm{Cu}_{2} \mathrm{Br}_{2}\right)_{3}$ propeller units are linked by infinite $\mathrm{CuBr}$ chains; acute $\mathrm{Cu}-\mathrm{Br}-\mathrm{Cu}$ angles are again present. No 3D halocuprates are known. 


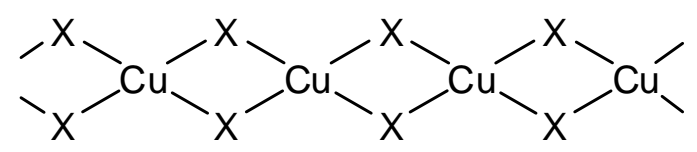

I

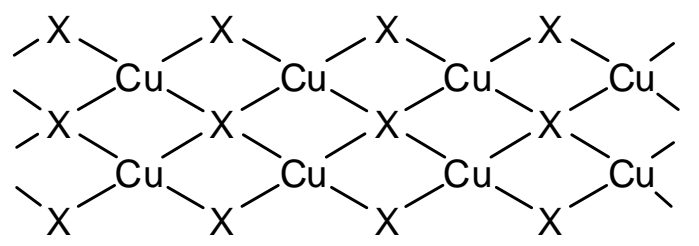

II

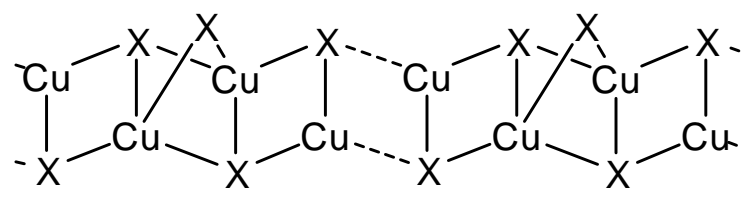

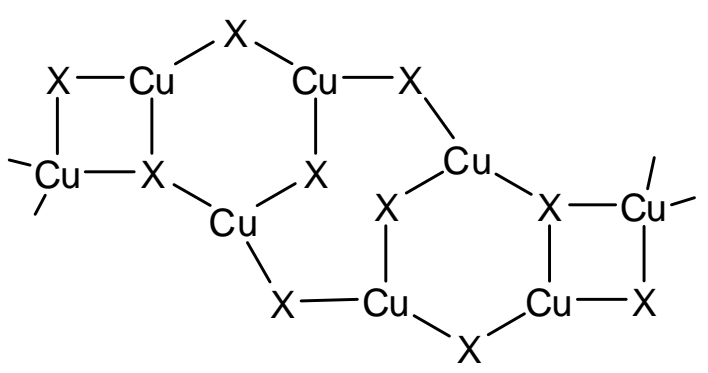

V<smiles>[X]C([X])[X]C([X])[Si]([X])([X])C([X])([X])[X]C([X])[X]</smiles>

VI

III

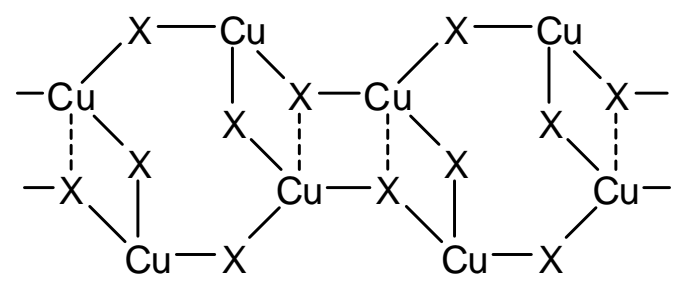

IV

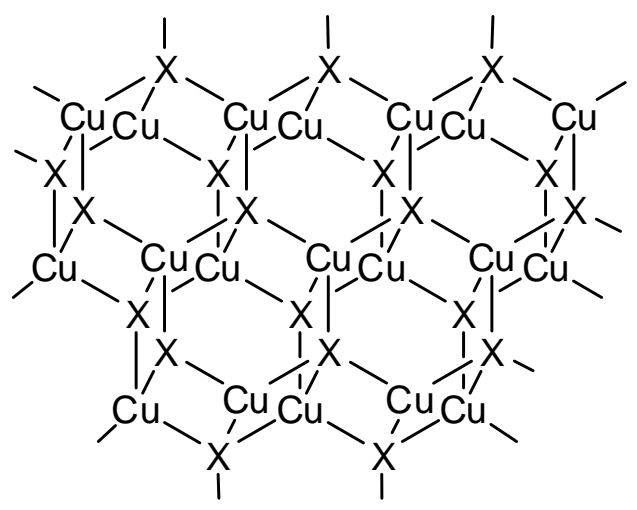

VII

\section{Experimental}

Synthesis.

Piperazinium tetrachlorodicuprate(I) (1A) A $20 \mathrm{~mL}$ aqueous solution containing $\mathrm{CuCl}_{2} \cdot 2 \mathrm{H}_{2} \mathrm{O}(0.852 \mathrm{~g}, 5.00 \mathrm{mmol})$ and $\mathrm{NH}_{2} \mathrm{OH} \cdot \mathrm{HCl}(0.348 \mathrm{~g}, 10.0 \mathrm{mmol})$ was warmed to about $70{ }^{\circ} \mathrm{C}$ in an open vessel. A $15 \mathrm{~mL}$ aqueous solution of piperazine $\left(\mathrm{C}_{4} \mathrm{H}_{10} \mathrm{~N}_{2}, 0.431 \mathrm{~g}, 5.00 \mathrm{mmol}\right)$ was added in drop-wise fashion. The blue-green color slowly discharged. The colorless solution was allowed to slowly cool first in a $40{ }^{\circ} \mathrm{C}$ water bath and then at room temperature, resulting in 
the formation of crystals, which were collected by filtration and washed with $95 \%$ ethanol and then diethyl ether $(0.604 \mathrm{~g}, 68.0 \%)$.

Piperazinium tetrachlorodicuprate(I) $(\mathbf{1 B})$ was prepared under similar conditions to those used for 1A, except that $10.0 \mathrm{mmol}$ piperazine was used. $(0.238 \mathrm{~g}, 26.8 \%)$

N-Methylpiperazinium pentachlorotricuprate(I) (2) was prepared under similar conditions to those used for $\mathbf{1 A}$, except that $\mathrm{N}$-methylpiperazine was used $\left(\mathrm{C}_{5} \mathrm{H}_{12} \mathrm{~N}_{2}, 0.278 \mathrm{~g}\right.$, $35.5 \%)$.

N,N'-Dimethylpiperazinium hexachlorotetracuprate(I) (3) was prepared under similar conditions to those used for $\mathbf{1 A}$, except that $\mathrm{N}, \mathrm{N}^{\prime}$-dimethylpiperazine was used $\left(\mathrm{C}_{6} \mathrm{H}_{14} \mathrm{~N}_{2}, 0.332\right.$ $\mathrm{g}, 45.5 \%)$.

$X$-ray crystallography.

Crystals were grown from the aqueous reaction mixtures as described above. Crystals were mounted on glass fibers. All measurements were made using graphite-monochromated $\mathrm{Cu}$ $\mathrm{K} \alpha$ radiation on a Bruker-AXS three-circle diffractometer, equipped with a SMART Apex II CCD detector. Initial space group determination was based on a matrix consisting of 120 frames. The data were reduced using SAINT,$+{ }^{9}$ and empirical absorption correction applied using SADABS. ${ }^{10}$

Structures were solved using direct methods. Least-squares refinement for all structures was carried out on $F^{2}$. The non-hydrogen atoms were refined anisotropically. Hydrogen atoms in 1A and 1B were located in the Fourier difference map and then allowed to refine isotropically; hydrogen atoms in $\mathbf{2}$ and $\mathbf{3}$ were placed in calculated positions attached to adjacent carbon and nitrogen atoms and allowed to refined isotropically as riding models. Structure solution, refinement and the calculation of derived results were performed using the SHELXTL package of computer programs. ${ }^{11}$ Packing diagrams were produced using Mercury. ${ }^{12}$ Details of the X-ray 
experiments and crystal data are summarized in Table 1. Selected bond lengths and bond angles are given in Table 2 and hydrogen-bonds are listed in Table 3.

\section{Results and Discussion}

Synthesis

The various chlorocuprates described herein (except for 1B) were prepared from aqueous reaction mixtures using 1:2:1 ratios of $\mathrm{CuCl}_{2} \bullet 2 \mathrm{H}_{2} \mathrm{O}: \mathrm{NH}_{2} \mathrm{OH} \bullet \mathrm{HCl}$ :Pip' (Pip' = Pip, MePip or $\mathrm{Me}_{2} \mathrm{Pip}$ ) Addition of Pip' to a hot solution of copper(II) chloride and hydroxylamine hydrochloride (the reducing agent) caused the blue-green $\mathrm{Cu}(\mathrm{II})$ color to discharge, resulting in colorless solutions which crystallized upon cooling. Structural determination of the various crystals revealed an interesting variety of polyanions.

The 1:2:1 $\mathrm{CuCl}_{2} \cdot 2 \mathrm{H}_{2} \mathrm{O}: \mathrm{NH}_{2} \mathrm{OH} \cdot \mathrm{HCl}: \mathrm{Pip}^{\prime}$ ratio used could be expected to produce $\left(\mathrm{H}_{2} \mathrm{Pip}^{\prime}\right)\left[\mathrm{CuCl}_{3}\right]$, as suggested by equation $(1), \mathrm{x}=1$. However, in no case was the simple trichlorocuprate(I) anion realized. Instead, a variety of higher chlorocuprates(I) was found, corresponding to a functionally variable $\mathrm{Cu}$ :Pip' ratio. The following product formulas were found: $\left(\mathrm{H}_{2} \mathrm{Pip}\right)\left[\mathrm{Cu}_{2} \mathrm{Cl}_{4}\right](\mathbf{1} \mathbf{A}, \mathrm{Cu}: \mathrm{Pip}=2: 1),\left(\mathrm{H}_{2} \mathrm{MePip}\right)\left[\mathrm{Cu}_{3} \mathrm{Cl}_{5}\right]$ (2, Cu:MePip = 3:1), and $\left(\mathrm{H}_{2} \mathrm{Me}_{2} \mathrm{Pip}\right)\left[\mathrm{Cu}_{4} \mathrm{Cl}_{6}\right]\left(3, \mathrm{Cu}: \mathrm{Me}_{2} \mathrm{Pip}=4: 1\right)$. In all cases an excess of copper over Pip' was noted in the product, despite the use of 1:1 reactant ratio. Therefore, an experiment was carried out using 1:2:2 $\mathrm{CuCl}_{2} \cdot 2 \mathrm{H}_{2} \mathrm{O}: \mathrm{NH}_{2} \mathrm{OH} \cdot \mathrm{HCl}$ :Pip in order to increase the Pip loading. Interestingly, instead of altering the $\mathrm{Cu}$ :Pip ratio, the result was formation of a product, $\mathbf{1 B}$, which was isomeric to $\mathbf{1 A}$. All of the products described herein are somewhat air-sensitive, decomposing to green $\mathrm{Cu}$ (II) materials over the course of several weeks when stored in air at reduced temperature.

$$
\mathrm{x} \mathrm{CuCl}_{2} \cdot 2 \mathrm{H}_{2} \mathrm{O}+2 \mathrm{NH}_{2} \mathrm{OH} \cdot \mathrm{HCl}+\mathrm{Pip}^{\prime} \rightarrow\left(\mathrm{H}_{2} \mathrm{Pip}^{\prime}\right)\left[\mathrm{Cu}_{\mathrm{x}} \mathrm{Cl}_{\mathrm{x}+2}\right]
$$

Piperazinium tetrachlorodicuprate(I) chain isomer (1A) 
Significant structural diversity was observed in the various chlorocuprate(I) polyanions prepared in the course of this study. The simplest of these networks was found for $\mathbf{1 A}$, which crystallizes in the triclinic space group $P-1$; a packing diagram is shown in Figure 1. Compound 1A is formed from a single independent copper atom and two chlorine atoms. The structure contains copper-sharing chains of rhomboid $\mathrm{Cu}_{2} \mathrm{Cl}_{2}$ dimers. The two $\mathrm{Cu} \cdots \mathrm{Cu}$ distances across the

dimer units measure 3.1620(7) and 3.1671(7) A, i.e. significantly larger than the van der Waals sum of two copper atoms $(2.8 \AA)$. The $\left(\mathrm{Cu}_{2} \mathrm{Cl}_{2}\right)_{\mathrm{n}}$ chains propagate parallel to the crystallographic $a$-axis. Formation of such chains is a very common phenomenon in halocuprate chemistry. ${ }^{1}$ As is the case with all of the networks reported herein, the dications (in this case $\mathrm{H}_{2} \mathrm{Pip}^{2+}$ ) are independent of the polyanions, except for the existence of $\mathrm{N}-\mathrm{H} \cdots \mathrm{Cl}$ hydrogen-bonding. The $\mathrm{H}_{2} \mathrm{Pip}^{2+}$ units are only half crystallographically independent, being centered about an inversion center. Hydrogen-bonding $\mathrm{N}(1)-\mathrm{H} \cdots \mathrm{Cl}(2)$ involves all Pip nitrogen atoms and half of the chlorides.

Piperazinium tetrachlorodicuprate(I) sheet isomer $(\mathbf{1 B})$

As described above, the use of additional Pip in the standard reaction did not alter the product formula, but instead produced an isomer of 1A. This isomer, 1B, crystallizes in the orthorhombic space group Pbcn. The chlorocuprate network in $\mathbf{1 B}$ forms an unusual honeycomb 2D sheet network, see Figure 2. The single independent copper center, $\mathrm{Cu} 1$, is linked by bridging atom $\mathrm{Cl} 2$ to form zigzag chains running parallel to the $b$-axis. Additionally, $\mathrm{Cl} 1$ knits the chains together parallel to the $a$-axis by forming $\mathrm{Cu}_{2} \mathrm{Cl}_{2}$ dimers. The resulting sheets contain hexagonal $\mathrm{Cu}_{6} \mathrm{Cl}_{8}$ units and are oriented parallel to the $a, b$-plane. The dimer $\mathrm{Cu} 1-\mathrm{Cl} 1-\mathrm{Cu} 1^{\prime}$ angle is typically acute at $77.53(4)^{\circ}$, however the in-plane $\mathrm{Cu} 1-\mathrm{Cl} 2-\mathrm{Cu} 1^{\prime}$ angle is almost twice as large at 149.03(6) ${ }^{\circ}$. The dimers in $\mathbf{1 B}$ have slightly more acute angles at $\mathrm{Cl}$ than do those in $\mathbf{1 A}$. This effect is reflected in a slightly shorter $\mathrm{Cu}^{\cdots} \mathrm{Cu}$ distance of $2.9645(16) \AA$. The half-independent $\mathrm{H}_{2} \mathrm{Pip}^{2+}$ ions lie between the chlorocuprate sheets and are aligned with the centers of the 
vacancies in the sheets, as is evident in the roughly $c$-axis projection, Figure 4 . Three interactions, two between $\mathrm{N} 1$ and $\mathrm{Cl} 1$ and one between $\mathrm{N} 1$ and $\mathrm{Cl}$, are sufficiently short to suggest hydrogenbonding.

\section{N-Methylpiperazinium pentachlorotricuprate(I) (2)}

The unsymmetrical $\mathrm{N}$-methylpiperazinium cation forms a 3:1 $\mathrm{Cu}: \mathrm{H}_{2} \mathrm{MePip}$ complex. The product, which is shown in Figures 5 and 6, crystallizes in the space group $P-1$. The $\mathrm{H}_{2} \mathrm{MePip}{ }^{2+}$ unit is fully independent, as are the three copper and five chlorine atoms. The pentachlorotricuprate(I) units incorporate 3-coordinate $\mathrm{Cu} 1$ and $\mathrm{Cu} 2$ and 4-coordinate $\mathrm{Cu} 3$. The latter coordinates an unusual terminal chloride, $\mathrm{Cl}$. The $\mathrm{Cu} 2$ atom shows a slight tendency toward 4-coordination. It features three normal length $\mathrm{Cu}-\mathrm{Cl}$ bonds: $\mathrm{Cu} 2-\mathrm{Cl} 2=2.2510(10)$, $\mathrm{Cu} 2-\mathrm{Cl1}^{\prime}=2.2928(10)$, and $\mathrm{Cu} 2-\mathrm{Cl}^{\prime}{ }^{\prime}=2.3527(10) \AA$. However, the resulting $\mathrm{Cl}-\mathrm{Cu}-\mathrm{Cl}$ angles add up to a total of about $354.5^{\circ}$. In addition, there is a pair of long $\mathrm{Cu} 2 \cdots \mathrm{Cl} 4$ interactions (not shown in Figures 5 and 6, shown dashed in VIII) measuring 2.9562(11) A. Weak interactions between copper atoms are present. The $\mathrm{Cu} 1 \cdots \mathrm{Cu} 2$ distance of $2.7109(8) \AA$ and the $\mathrm{Cu} 1 \cdots \mathrm{Cu} 3$ distance of 2.8751(8) $\AA$ are both close to the van der Waals radius sum. The overall structure of the chlorocuprate network is a novel ribbon structure, VIII, propagating parallel to the crystallographic $a$-axis and which is closely related to known halocuprate networks $\mathbf{I V}, \mathbf{V}$, and VI. The methyl-bearing nitrogen atom, N1, shows a single hydrogen-bonding interaction to $\mathrm{Cl} 5$. The $\mathrm{NH}_{2}$ nitrogen atom, $\mathrm{N} 2$, shows potential hydrogen-bonding interactions to $\mathrm{Cl} 3, \mathrm{Cl} 4$ and $\mathrm{Cl} 5$. However, as was the case for $\mathbf{1 B}$, only two of these interactions are formally allowable, given the presence of only two hydrogen atoms at this site. 


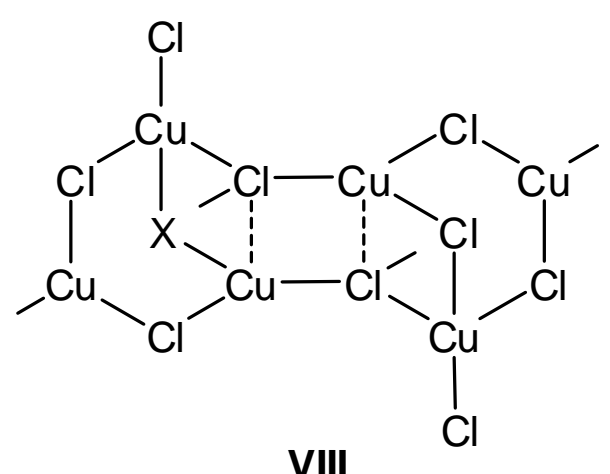

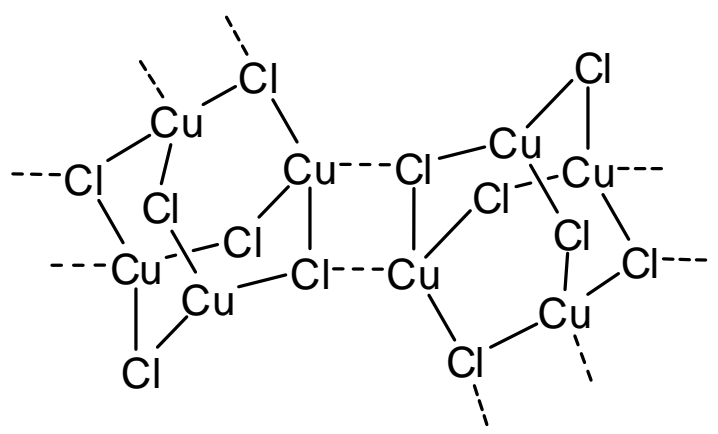

IX

\section{N,N'-Dimethylpiperazinium hexachlorotetracuprate(I) (3)}

The dimethylpiperazinium chlorocuprate network crystallizes in monoclinic space group $C 2 / c$. The chlorocuprate anions (see Figures 7 and 8 ) consist of tetrahedral adamantane-like $\mathrm{Cu}_{4} \mathrm{Cl}_{6}{ }^{2-}$ units that weakly link together to form ribbons running parallel to the crystallographic $c$-axis. Two independent copper atoms are present: 3 -coordinate $\mathrm{Cu} 1$ and roughly 3 -coordinate $\mathrm{Cu} 2$. The latter shows three regular $\mathrm{Cu}-\mathrm{Cl}$ bonds: $\mathrm{Cu} 2-\mathrm{Cl} 3=2.2645(5), \mathrm{Cu} 2-\mathrm{Cl}^{\prime}=2.3052(5)$, and $\mathrm{Cu} 2-$ $\mathrm{Cl} 4=2.3242(5)$. However, the $\mathrm{Cl}-\mathrm{Cu}-\mathrm{Cl}$ angles total to only about $355.8^{\circ}$. An additional pair of long $\mathrm{Cu} 2 \cdots \mathrm{Cl} 3$ interactions measuring 2.7623(6) $\AA$ link the $\mathrm{Cu}_{4} \mathrm{Cl}_{6}{ }^{2-}$ units together to form a ribbon running parallel to the $c$-axis (see Figure 8). An even longer pair of $\mathrm{Cu} 1 \cdots \mathrm{Cl} 1$ interactions measuring 3.0568(5) $\AA$ (slightly under the van der Waals sum of $3.15 \AA$ ) further links the ribbons in a direction between the $a$ - and $b$-axes to form a 2D sheet network (see $\mathbf{I X}$ ). All of the chloride atoms form simple bridges between copper centers, except $\mathrm{Cl} 3$, which (taking into account the long $\mathrm{Cu} 2 \cdots \mathrm{Cl} 3$ bond) is triply bridging and in T-shaped geometry. $\mathrm{All} \mathrm{Cu}-\mathrm{Cl}-\mathrm{Cu}$ bond angles within the polyhedra are in the range of $77.152(18)$ to $89.10(3)^{\circ}$. The $\mathrm{Cu}_{4} \mathrm{X}_{6}{ }^{2-}$ unit is widely recognized in $\mathrm{Cu}(\mathrm{I})$ halide networks, ${ }^{8 \mathrm{a}, 13}$ but linking of these units into ribbons has only a single precident. ${ }^{6 c}$ The two hydrogen-bonding interactions in $\mathbf{3}$ involve the proton attached to $\mathrm{N} 1$ and the chlorocuprate $\mathrm{Cl} 1$ and $\mathrm{Cl} 3$ atoms.

\section{Conclusions}


Four new piperazinium salt structures were added the known catalog of halocuprate coordination modes. Network 1B is a very rare example of a chlorocuprate forming a 2D sheet structure and networks $\mathbf{2}$ and $\mathbf{3}$ are relatively unusual examples of chlorocuprate ribbons formed from linking of polyhedra.

Supplementary Material: Tables of atomic coordinates for each structure are avialable as supplementary material. CCDC 679163-679166 contain the crystallographic data for this paper. These data can be obtained free of charge by e-mailing data_request@ccdc.cam.ac.uk or by contacting The Cambridge Crystallographic Data Centre, 12 Union Road, Cambridge, CB2 1EZ UK; Fax +44(0)1223-336033; www.ccdc.cam.ac.uk/data_request/cif.

Acknowledgement. This research was supported in part by donors of the American Chemical Society Petroleum Research Fund (44891-B3). We are indebted to NSF (CHE-0443345) and the College of William and Mary for the purchase of the X-ray equipment.

\section{References}

1 (a) B.Freckmann, K.-F.Tebbe Z. Naturforsch. B 1980 B35, 1319. (b) H.Hartl, I.Brudgam, F.Mahdjour-Hassan-Abadi Z. Naturforsch. B 1983 38, 57. (c) O.Simonsen, H.Toftlund Acta Crystallogr., Sect. C 1987 43, 843. (d) Willett, R. D. Inorg. Chem. 1987 26, 3423. (e) B.Scott, R.Willett, L.Porter, J.Williams Inorg. Chem. 1992 31, 2483. (f) B.Scott, R.Willett, A.Saccani, F.Sandrolini, B.L.Ramakrishna Inorg. Chim. Acta 1996 248, 73. (g) R.P.Hammond, D.J.Chesnut, J.A.Zubieta J. Solid State Chem. 2001 55, 158. (h) R.D.Willett, B.Twamley Inorg. Chem. 2004 43, 954.

2 (a) J.R.Boehm, A.L.Balch, K.F.Bizot, J.H.Enemark J. Am. Chem. Soc. 1975 97, 501. (b) H.Hartl, F.Mahdjour-Hassan-Abadi Z. Naturforsch. B 1984 39, 149. (c) S.Andersson, S.Jagner Acta Chem. Scand. A 1986 40, 177. (d) R.Frydrych, T.Muschter, I.Brudgam, 
H.Hartl Z. Naturforsch. B 1990 45, 679. (e) B.R.Cabrera, Ru-Ji Wang, Jing Li, Tan Yuen Mat.Res.Soc.Symp.Proc. 1999 547, 493. (f) R.P.Hammond, M.Cavaluzzi, R.C.Haushalter, J.A.Zubieta Inorg. Chem. 1999 38, 1288.

(a) A.S.Batsanov, Yu.T.Struchkov, L.Yu.Ukhin, N.A.Dolgopolova Ramakrishna Inorg.

Chim. Acta 1982 63, 17. (b) N.P.Rath, E.M.Holt Chem. Commun. 1985 665. (c) S.Myllyviita, R.Sillanpaa J. Chem. Soc., Dalton Trans. 1994 2125. (d) G.Hu, E.M.Holt Acta Crystallogr., Sect. C 1994 50, 1578. (e) A.K.Nurtaeva, G. Hu, E.M.Holt Acta Crystallogr., Sect. C 1998 54, 594. (f) H.Paulsson, A.Fischer, L.Kloo Acta Crystallogr., Sect. E 2004 60, m548.

(a) S.Andersson, S.Jagner Acta Chem., Scand. A 1988 42, 691. (b) B.M.Mykhalichko Zh.Neorg.Khim.(Russ.)(Russ.J.Inorg.Chem.) 1998 43, 1840. (c) A.V.Pavlyuk, V.N.Davydov, M.G.Mys'kiv Koord.Khim.(Russ.)(Coord.Chem.) 2001 27, 917. (d) M.A.S.Goher, A.K.Hafez, T.C.W.Mak Polyhedron 2001 20, 2583. (e) A.V.Pavlyuk, V.N.Davydov, M.G.Mys'kiv Koord.Khim.(Russ.)(Coord.Chem.) 2003 29, 213.

(a) R.J.Baker, S.C.Nyburg, J.T.Szymanski Inorg. Chem. 1971 10, 138. (b) M.Asplund, S.Jagner Acta Chem., Scand. A 1984 38, 807.

(a) J.D.Martin, A.M.Dattelbaum, T.A.Thornton, R.M.Sullivan, J.Yang, M.T.Peachey Chem. Mater. 1998 10, 2699. (b) A.V.Mikhalichko, M.G.Mys'kiv Zh.Strukt.Khim.(Russ.)(J.Struct.Chem.) 1999 40, 1160. (c) H. Zhao, Z.-R. Qu, Q.Ye, B.F.Abrahams, Y.-P.Wang, Z.-G.Liu, Z.Xue, R.-G.Xiong, X.-Z.You Chem Mater. 2003 $15,4166$.

7 (a) R.P.Shibaeva, R.M.Lobkovskaya, V.E.Korotkov, N.D.Kushch, E.B.Yagubskii, M.K.Makova Synth. Met. 1988 27, 457. (b) H.Place, B.Scott, G.S.Long, R.D.Willett Inorg. Chim. Acta 1998 279, 1. (c) E.Cariati, R.Ugo, F.Cariati, D.Roberto, N.Masciocchi, S.Galli, A.Sironi Adv. Mater. 2001 13, 1665. 
(a) N.P.Rath, E.M.Holt Chem. Commun. 1985 665. (b) H.-G.Zhu, Z.Yu, H.Cai, X.Z.You, J.J.Vittal, G.-K. Tan Chem. Lett. 1999298.

9 SAINT PLUS: Bruker Analytical X-ray Systems: Madison, WI, 2001.

10 SADABS: Bruker Analytical X-ray Systems: Madison, WI, 2001.

11 G.M.Sheldrick Acta Crystallogr., Sect. A 2008, 64, 112.

12 Mercury 1.4.2: Cambridge Crystallographic Data Centre: Cambridge, U.K. 2007.

13 (a) G.A.Bowmaker, G.R.Clark, D.K.P.Yuen J. Chem. Soc., Dalton Trans. 1976, 2329. (b)

M.Asplund, S.Jagner Acta Chem. Scand. 1984, A38, 725. (c) S.Anderson, S.Jagner Acta Chem. Scand. 1986, A40, 210. (d) J.T.Mague Acta Crystallogr., Sect. C 1998 54, 9800010. (e) A.Nurtaeva, E.M.Holt Acta Crystallogr., Sect. C 1999, 55, 1453. (f) D.Gudat, A.W.Holderberg, N.Kobar, M.Nieger, M.Schrott, Z. Naturforsch. 1999, B54, 1244. (g) J.A.Rusanova, K.V.Dornasevitch, O.Y.Vassilyeva, V.N.Kokozay, E.G.Rusanov, S.G.Nedelko, O.V.Chukova, B.Ahrens, P.R.Raithby J. Chem. Soc., Dalton Trans. 2000, 2175. (h) S.Hasselgren, S.Jagner Inorg. Chim. Acta 2002, 336, 137. 
Table 1. Crystal and Structure Refinement Data. ${ }^{\mathrm{a}}$

\begin{tabular}{|c|c|c|c|}
\hline & $1 \mathrm{~A}$ & $1 B$ & 2 \\
\hline CCDC deposit no. & 679163 & 679164 & 679165 \\
\hline color and habit & colorless needle & colorless blade & colorless blade \\
\hline size, $\mathrm{mm}$ & $0.42 \times 0.08 \times 0.07$ & $0.30 \times 0.10 \times 0.02$ & $0.33 \times 0.11 \times 0.03$ \\
\hline formula & $\mathrm{C}_{2} \mathrm{H}_{6} \mathrm{Cl}_{2} \mathrm{Cu}_{1} \mathrm{~N}_{1}$ & $\mathrm{C}_{4} \mathrm{H}_{12} \mathrm{Cl}_{4} \mathrm{Cu}_{2} \mathrm{~N}_{2}$ & $\mathrm{C}_{5} \mathrm{H}_{14} \mathrm{Cl}_{5} \mathrm{Cu}_{3} \mathrm{~N}_{2}$ \\
\hline formula weight & 178.52 & 178.52 & 470.05 \\
\hline space group & $P-1(\# 2)$ & Pbcn (\#60) & $P-1(\# 2)$ \\
\hline$a, \AA$ & $6.3141(2)$ & $9.9442(6)$ & $8.0815(7)$ \\
\hline$b, \AA$ & $6.8248(2)$ & $8.0622(5)$ & $9.6584(9)$ \\
\hline$c, \AA$ & $6.9067(2)$ & $13.1301(7)$ & $9.7900(8)$ \\
\hline$\alpha, \operatorname{deg}$ & $90.707(2)$ & 90 & $70.231(4)$ \\
\hline$\beta, \operatorname{deg}$ & $110.748(2)$ & 90 & $77.180(4)$ \\
\hline$\gamma, \operatorname{deg}$ & $110.799(2)$ & 90 & $70.587(4)$ \\
\hline volume, $\AA^{3}$ & $256.918(13)$ & $1052.67(11)$ & $673.05(10)$ \\
\hline $\mathrm{Z}$ & 2 & 8 & 2 \\
\hline$\rho_{\text {calc }}, \mathrm{g} \mathrm{cm}^{-3}$ & 2.308 & 2.253 & 2.319 \\
\hline $\mathrm{F}_{000}$ & 176 & 704 & 460 \\
\hline$\mu(\mathrm{Cu} \mathrm{K} \alpha), \mathrm{mm}^{-1}$ & 14.251 & 13.913 & 14.387 \\
\hline \multirow[t]{2}{*}{ radiation } & $\mathrm{CuK} \alpha$ & $\mathrm{CuK} \alpha$ & $\mathrm{CuK} \alpha$ \\
\hline & $(\lambda=1.54178 \AA)$ & $(\lambda=1.54178 \AA)$ & $(\lambda=1.54178 \AA)$ \\
\hline temperature, $\mathrm{K}$ & 200 & 200 & 100 \\
\hline residuals: ${ }^{\mathrm{a}} \mathrm{R} ; \mathrm{R}_{\mathrm{w}}$ & $0.0282 ; 0.0715$ & $0.0394 ; 0.1145$ & $0.0383 ; 0.1043$ \\
\hline goodness of fit & 1.089 & 1.047 & 1.059 \\
\hline
\end{tabular}


${ }^{\mathrm{a}} \mathrm{R}=R_{l}=\Sigma|| F_{o}|-| F_{c} \| / \Sigma\left|F_{o}\right|$ for observed data only. $\mathrm{R}_{\mathrm{w}}=w R_{2}=\left\{\Sigma\left[w\left(F_{o}^{2}-F_{c}^{2}\right)^{2}\right] / \Sigma\left[w\left(F_{o}^{2}\right)^{2}\right]\right\}^{1 / 2}$ for all data. 
Table 1. (cont'd)

\begin{tabular}{|c|c|}
\hline & 3 \\
\hline CCDC deposit no. & 679166 \\
\hline color and habit & colorless prism \\
\hline size, $\mathrm{mm}$ & $0.18 \times 0.07 \times 0.06$ \\
\hline formula & $\mathrm{C}_{3} \mathrm{H}_{8} \mathrm{Cl}_{3} \mathrm{Cu}_{2} \mathrm{~N}$ \\
\hline formula weight & 291.53 \\
\hline space group & $C 2 / c(\# 15)$ \\
\hline$a, \AA$ & $17.4026(6)$ \\
\hline$b, \AA$ & $10.5295(4)$ \\
\hline$c, \AA$ & $11.7501(8)$ \\
\hline$\alpha, \operatorname{deg}$ & 90 \\
\hline$\beta, \operatorname{deg}$ & $131.5490(10)$ \\
\hline$\gamma, \operatorname{deg}$ & 90 \\
\hline volume, $\AA^{3}$ & $1611.35(14)$ \\
\hline $\mathrm{Z}$ & 8 \\
\hline$\rho_{\text {calc }}, \mathrm{g} \mathrm{cm}^{-3}$ & 2.403 \\
\hline $\mathrm{F}_{000}$ & 1136 \\
\hline$\mu(\mathrm{Cu} \mathrm{K} \alpha), \mathrm{mm}^{-1}$ & 14.948 \\
\hline \multirow[t]{2}{*}{ radiation } & $\mathrm{CuK} \alpha$ \\
\hline & $(\lambda=1.54178 \AA)$ \\
\hline temperature, $\mathrm{K}$ & 100 \\
\hline residuals: ${ }^{\mathrm{a}} \mathrm{R} ; \mathrm{R}_{\mathrm{w}}$ & $0.0191 ; 0.0455$ \\
\hline goodness of fit & 1.105 \\
\hline
\end{tabular}


${ }^{\mathrm{a}} \mathrm{R}=R_{l}=\Sigma|| F_{o}|-| F_{c} \| / \Sigma\left|F_{o}\right|$ for observed data only. $\mathrm{R}_{\mathrm{w}}=w R_{2}=\left\{\Sigma\left[w\left(F_{o}^{2}-F_{c}^{2}\right)^{2}\right] / \Sigma\left[w\left(F_{o}^{2}\right)^{2}\right]\right\}^{1 / 2}$ for all data. 
Table 2. Selected Bond Distances $(\AA)$ and Angles $\left({ }^{\circ}\right)$.

\begin{tabular}{|c|c|c|c|c|}
\hline & $\mathbf{1 A}$ & 1B & 2 & 3 \\
\hline \multirow[t]{6}{*}{$\mathrm{Cu}-\mathrm{Cl}$} & $2.3798(7)$ & 2.3234(12), & 2.2265(10), 2.2363(10), & $2.2577(6), 2.2645(5)$ \\
\hline & 2.3923(7), & 2.4103(13), & 2.2510(10), 2.2929(10), & $2.2840(5), 2.3052(5)$ \\
\hline & $2.3466(7)$ & 2.3797(13), & 2.3255(9), 2.3392(10), & $2.3242(5), 2.3262(5)$ \\
\hline & $2.4064(7)$ & $2.4052(13)$ & 2.3528(10), 2.3704(10), & $2.7623(6)^{\mathrm{a}}, 3.0568(5)^{\mathrm{a}}$ \\
\hline & & & 2.3797(10), 2.4195(10), & \\
\hline & & & $2.9562(11)^{\mathrm{a}}$ & \\
\hline \multirow[t]{2}{*}{$\mathrm{Cu} \cdots \mathrm{Cu}$} & $3.1620(7)$ & $2.9645(16)$ & $2.7109(8), 2.8751(8)$ & $2.8616(4), 2.8759(6)$ \\
\hline & $3.1671(7)$ & & & $2.8794(4)$ \\
\hline \multirow[t]{6}{*}{$\mathrm{Cl}-\mathrm{Cu}-\mathrm{Cl}$} & $96.45(2)$ & 101.98(4), & $85.94(3)^{\mathrm{a}}, 97.58(3), 99.47(4)^{\mathrm{a}}$ & $88.057(18)^{\mathrm{a}}, 96.549(18)^{\mathrm{a}}$, \\
\hline & $96.99(2)$ & 107.30(5), & 105.70(4), 106.99(3), 107.44(4), & $103.228(18)^{\mathrm{a}}$ \\
\hline & 108.97(3), & 107.63(5), & 107.96(4), 108.25(3), 110.72(3) & 107.518(16), \\
\hline & 116.02(3), & 109.16(5), & 110.92(4), 111.20(4), 112.02(4), & 115.401(19), 116.21(2), \\
\hline & 119.47(3), & 114.43(5), & $124.04(4), 136.73(4), 137.84(4)$ & 117.064(19), \\
\hline & $119.78(3)$ & $115.25(4)$ & & $126.187(17), 132.88(2)$ \\
\hline \multirow[t]{3}{*}{$\mathrm{Cu}-\mathrm{Cl}-\mathrm{Cu}$} & 83.01(2), & 77.53(4), & $68.97(3)^{\mathrm{a}}, 69.28(3)^{\mathrm{a}}, 74.52(3)$ & 76.771(17) $)^{\mathrm{a}}, 77.152(18)$ \\
\hline & $83.55(2)$ & $149.03(6)$ & 78.11(3), 82.31(3), 104.53(4), & 77.677(18), 79.12(3), \\
\hline & & & $111.56(4), 123.52(4)$ & $89.10(3), 151.75(2)^{\mathrm{a}}$ \\
\hline
\end{tabular}

${ }^{a}$ Values associated with long $\mathrm{Cu}{ }^{\cdots} \mathrm{Cl}$ interactions. 
Table 3. Hydrogen-bond Distances $(\AA)$ and Angles $\left({ }^{\circ}\right)$.

\begin{tabular}{|c|c|c|c|c|c|}
\hline Network & $\mathrm{D}-\mathrm{H} \cdots \mathrm{A}$ & D-H dist. & $\mathrm{H}^{\cdots} \mathrm{A}$ dist. & $\mathrm{D} \cdots \mathrm{A}$ dist. & $\mathrm{D}-\mathrm{H} \cdots \mathrm{A}$ angle \\
\hline \multirow[t]{4}{*}{$\mathbf{1 A}$} & $\mathrm{N} 1-\mathrm{H} 2 \cdots \mathrm{Cl} 1^{\mathrm{a}}$ & $0.88(3)$ & $2.48(3)$ & $3.307(2)$ & $158(3)$ \\
\hline & $\mathrm{N} 1-\mathrm{H} 1 \cdots \mathrm{Cl} 2^{\mathrm{b}}$ & $0.86(5)$ & $2.67(4)$ & $3.306(2)$ & $132(3)$ \\
\hline & $\mathrm{N} 1-\mathrm{H} 1 \cdots \mathrm{Cl} 1^{\mathrm{b}}$ & $0.86(5)$ & $2.78(4)$ & $3.361(2)$ & $126(3)$ \\
\hline & $\mathrm{N} 1-\mathrm{H} 1 \cdots \mathrm{Cl} 2^{\mathrm{c}}$ & $0.86(5)$ & $2.87(4)$ & $3.242(2)$ & $108(3)$ \\
\hline \multirow[t]{4}{*}{$1 B$} & $\mathrm{~N} 1-\mathrm{H} 2 \cdots \mathrm{Cl} 2^{\mathrm{d}}$ & $0.76(6)$ & $2.98(5)$ & $3.420(4)$ & $120(4)$ \\
\hline & $\mathrm{N} 1-\mathrm{H} 2 \cdots \mathrm{Cl} 1^{\mathrm{e}}$ & $0.76(6)$ & $2.71(5)$ & $3.177(4)$ & $121(4)$ \\
\hline & $\mathrm{N} 1-\mathrm{H} 2 \cdots \mathrm{Cl} 1^{\mathrm{d}}$ & $0.76(6)$ & $2.62(5)$ & $3.171(4)$ & $131(4)$ \\
\hline & $\mathrm{N} 1-\mathrm{H} 1 \cdots \mathrm{Cl} 2^{\mathrm{f}}$ & $0.89(6)$ & $2.33(6)$ & $3.209(4)$ & $170(5)$ \\
\hline \multirow[t]{5}{*}{2} & $\mathrm{~N} 1-\mathrm{H} 1 \cdots \mathrm{Cl} 5^{\mathrm{g}}$ & 0.93 & 2.12 & $3.045(3)$ & 172.7 \\
\hline & $\mathrm{N} 2-\mathrm{H} 2 \mathrm{C} \cdots \mathrm{Cl} 4^{\mathrm{h}}$ & 0.92 & 2.31 & $3.200(3)$ & 163.6 \\
\hline & $\mathrm{N} 2-\mathrm{H} 2 \mathrm{D} \cdots \mathrm{Cl} 5$ & 0.92 & 2.38 & $3.132(3)$ & 138.3 \\
\hline & $\mathrm{N} 2-\mathrm{H} 2 \mathrm{D} \cdots \mathrm{Cl} 3^{\mathrm{h}}$ & 0.92 & 2.81 & $3.258(3)$ & 111.1 \\
\hline & $\mathrm{N} 2-\mathrm{H} 2 \mathrm{D} \cdots \mathrm{Cl} 3$ & 0.92 & 2.85 & $3.381(3)$ & 118.3 \\
\hline \multirow[t]{2}{*}{3} & $\mathrm{~N} 1-\mathrm{H} 1 \cdots \mathrm{Cl} 1^{\mathrm{i}}$ & 0.93 & 2.64 & $3.2848(17)$ & 127.0 \\
\hline & $\mathrm{N} 1-\mathrm{H} 1{ }^{\cdots} \mathrm{Cl}^{\mathrm{j}}$ & 0.93 & 2.64 & $3.3094(16)$ & 129.2 \\
\hline
\end{tabular}

Symmetry transformations used to generate equivalent atoms: ${ }^{\mathrm{a}}-\mathrm{x}+1,-\mathrm{y}+1,-\mathrm{z}+1 ;{ }^{\mathrm{b}} \mathrm{x}, \mathrm{y}+1, \mathrm{z}$;

${ }^{\mathrm{c}}-\mathrm{x}+1,-\mathrm{y}+1,-\mathrm{z}+2 ;{ }^{\mathrm{d}}-\mathrm{x}+1,-\mathrm{y}+1,-\mathrm{z}+1 ;{ }^{\mathrm{e}} \mathrm{x}+1, \mathrm{y}-1, \mathrm{z} ;{ }^{\mathrm{f}}-\mathrm{x}+3 / 2, \mathrm{y}-1 / 2, \mathrm{z} ;{ }^{\mathrm{g}}-\mathrm{x}+1,-\mathrm{y}+2,-\mathrm{z}+1$;

${ }^{\mathrm{h}}-\mathrm{x}+1,-\mathrm{y}+1,-\mathrm{z}+1 ;{ }^{\mathrm{i}}-\mathrm{x}+1 / 2, \mathrm{y}-1 / 2,-\mathrm{z}+1 / 2 ;{ }^{\mathrm{j}}-\mathrm{x}+1 / 2,-\mathrm{y}+1 / 2-\mathrm{z}$. 


\section{Captions for Figures.}

Figure 1. Thermal ellipsoid (50\%) drawing of $\mathbf{1 A .}$

Figure 2. Network and packing diagram for 1A. Hydrogen atoms omitted for clarity.

Figure 3. Thermal ellipsoid (50\%) drawing of $\mathbf{1 B}$.

Figure 4. Network and packing diagram for 1B. Hydrogen atoms omitted for clarity.

Figure 5. Thermal ellipsoid (50\%) drawing of 2.

Figure 6. Network and packing diagram for 2. Hydrogen atoms omitted for clarity.

Figure 7. Thermal ellipsoid (50\%) drawing of $\mathbf{3}$.

Figure 8 . Network and packing diagram for 3. Hydrogen atoms omitted for clarity. 
Figure 1. Thermal ellipsoid (50\%) drawing of $\mathbf{1 A .}$

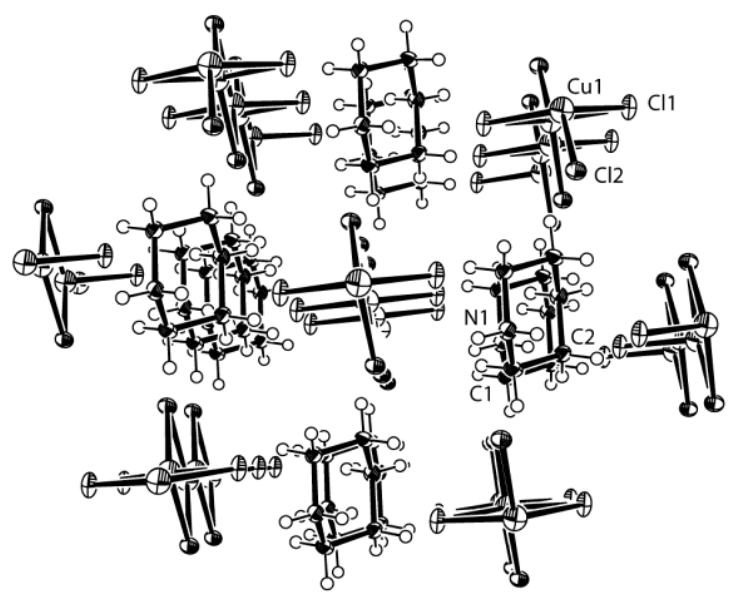

Figure 2. Network and packing diagram for 1A. Hydrogen atoms omitted for clarity.

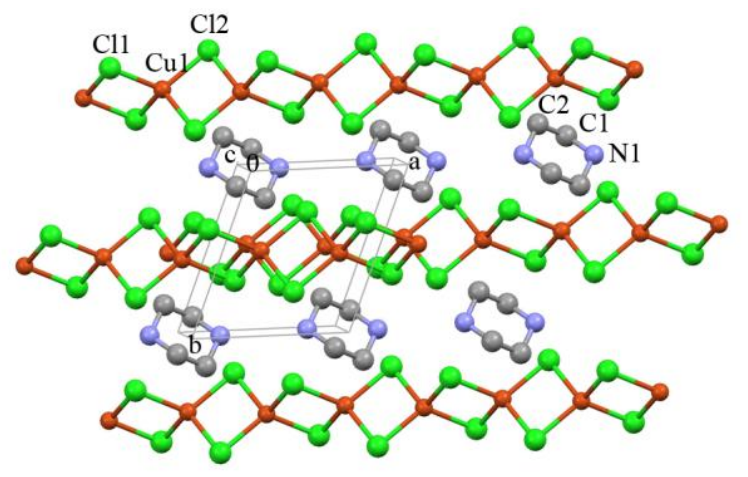


Figure 3. Thermal ellipsoid (50\%) drawing of 1B.

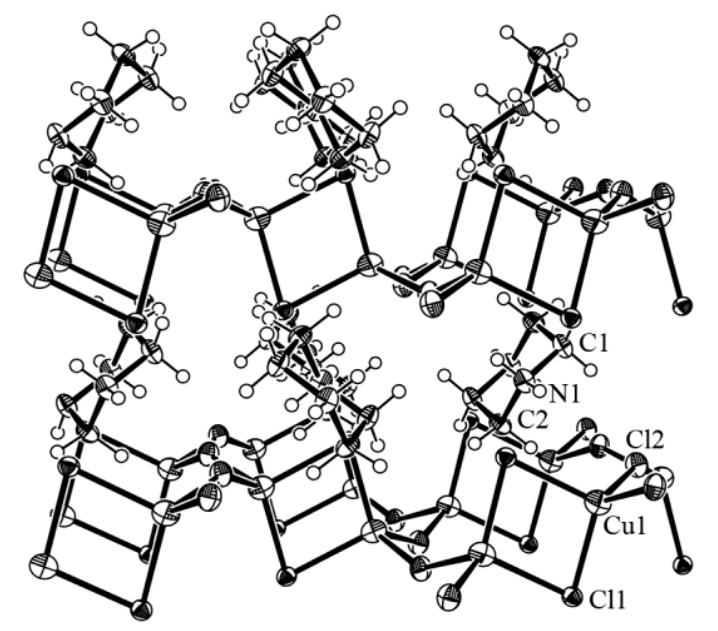

Figure 4. Network and packing diagram for 1B. Hydrogen atoms omitted for clarity.

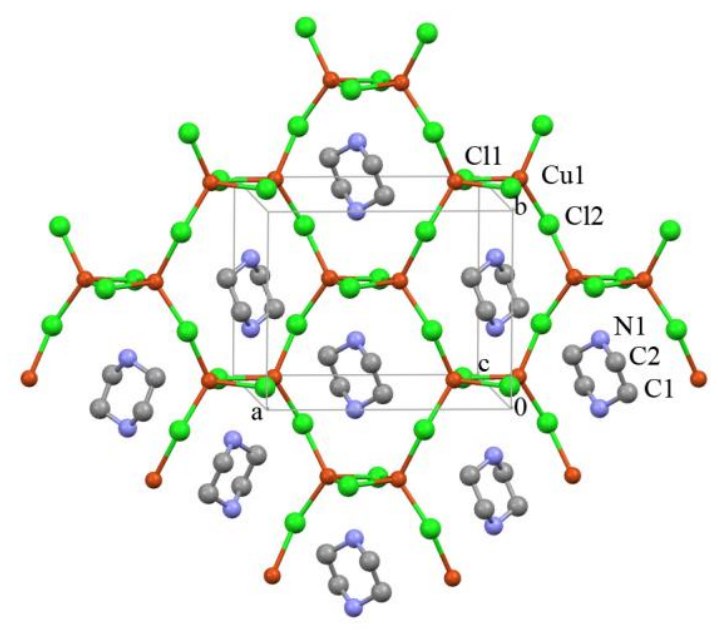


Figure 5. Thermal ellipsoid (50\%) drawing of 2.

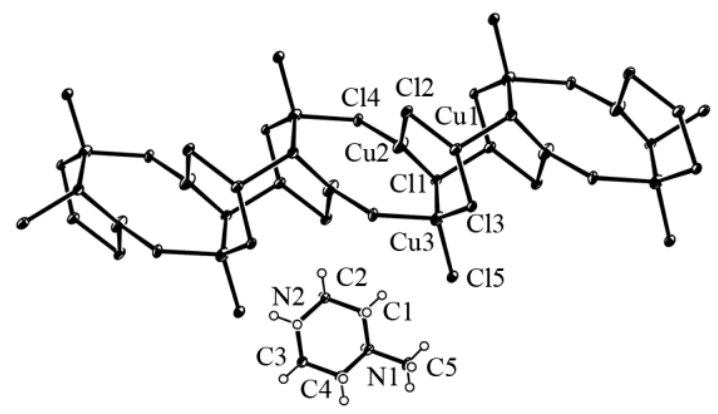

Figure 6. Network and packing diagram for 2. Hydrogen atoms omitted for clarity.

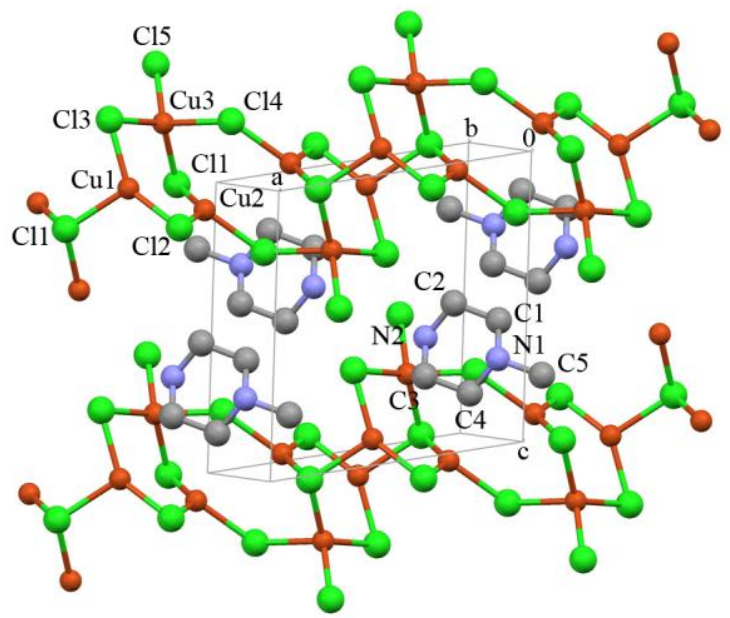


Figure 7. Thermal ellipsoid (50\%) drawing of 3.

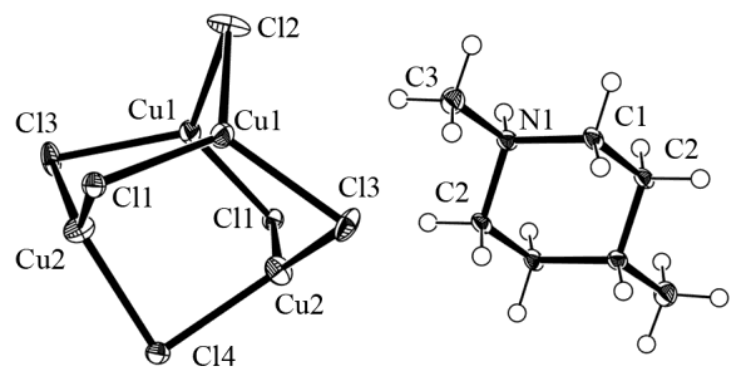

Figure 8. Network and packing diagram for 3. Hydrogen atoms omitted for clarity.

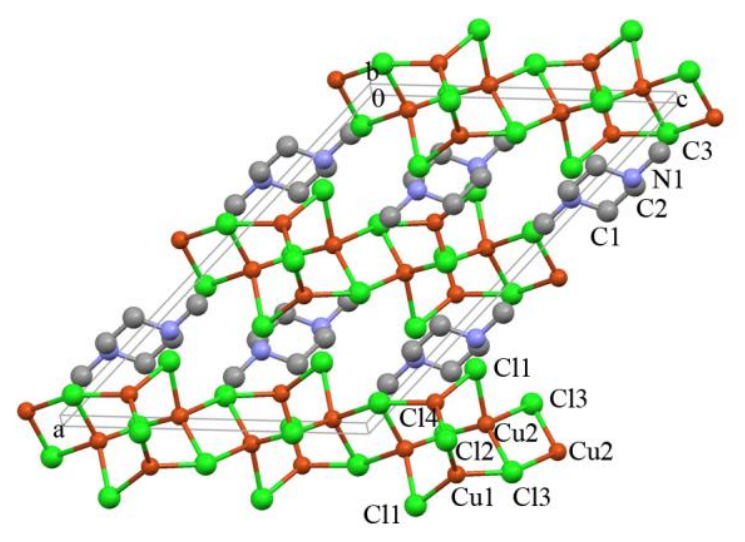

